\title{
Idea IV Rzeczypospolitej jako antidotum środowiska „Kwartalnika Konserwatywnego" na kryzys państwa
}

\section{Uwagi wstępne}

Dojęcie IV Rzeczypospolitej zdominowało polską debatę publiczną pierwszej dekady XXI wieku. Oznaczać miało ono odnowę państwa znajdującego się w „kryzysie”, owładniętego przez korupcję oraz zakulisowe rozgrywki na styku polityki oraz biznesu. Forowana przez środowisko Prawa i Sprawiedliwości koncepcja nie była jednak pomysłem nowatorskim, podobnie jak i określenie użyte dla jej nazwania. Już w pierwszej połowie lat 90. w Porozumieniu Centrum, z którego PiS się wywodzi, pojawiła się idea transformacji, która zmierzać powinna ku budowie nowego państwa, niebędącego strukturalną kontynuacją aparatu stworzonego przez PRL ${ }^{1}$. Pojęcie IV RP powstało jednak w zupełnie innej grupie politycznej. Prawdziwym jego autorem był Rafał Matyja związany wówczas z Koalicją Konserwatywną. Tym pojęciem określał on potrzebę budowy nowych struktur państwa będącego

Lider ugrupowania, Jarosław Kaczyński, proponował zarówno rzetelną ocenę i rozliczenie okresu PRL-u, dekomunizację oraz lustrację, jak również rekonstrukcję państwa: przywrócenie samorządu terytorialnego i budowę jego drugiego stopnia, przebudowę centrum adminsitracji terenowej oraz wojska, służb specjalnych i policji. Zob. J. Kaczyński, Budowa nowego państwa, „Nowe Państwo” 1996, nr 35, s. 5. 
dotychczas $\mathrm{w}$ kryzysie ${ }^{2}$. Zapewne obie koncepcje zmierzały w podobnym kierunku i posiadały szereg postulatów wspólnych, czego dowodem może być fakt, iż środowisko nieistniejącej już wówczas Koalicji Konserwatywnej w 2001 roku podjęło współpracę z PiS-em.

Warto zatem zastanowić się, co faktycznie oznaczała pierwotna idea IV RP oraz jakie przejawy kryzysu państwa legły u podstaw tegoż intelektualnego projektu? Taki też cel przyświeca niniejszemu artykułowi. Rozważania w nim czynione opierają się w głównej mierze na rozważaniach publicystów „Kwartalnika Konserwatywnego”, pisma prezentującego w głównej mierze poglądy środowiska politycznego związanego z Rafałem Matyją oraz Kazimierzem M. Ujazdowskim ${ }^{3}$. Podjęte rozważania dotyczą okresu drugiej połowy lat 90 . XX wieku, kiedy to na łamach takich pism, jak „Życie”, „Debata”, „Nowe Państwo” oraz właśnie „Kwartalnik Konserwatywny" idea IV RP pojawiła się w dużej mierze.

W odniesieniu do podjętego tematu konieczne jest dokonanie zastrzeżenia, iż na temat konserwatywnej wizji ustroju politycznego Polski po 1989 roku swoje koncepcje zaprezentowali m.in. Bogdan Borowik ${ }^{4}$ oraz Stefan Stępien $^{5}$, w obu jednak wypadkach, nie wyodrębniając szczególnie propozycji intelektualnej IV RP.

\section{„Kwartalnik Konserwatywny"}

Aby dokonać recepcji idei budowy „nowego państwa” warto dookreślić środowisko występujące pod nazwą „Kwartalnika Konserwatywnego”.

Matyja używa zwrotu „Czwarta Rzeczpospolita” w ramach zwrócenia uwagi, iż państwo polskie po 1989 roku nie posiada tożsamości, nie ma oddanych sobie obywateli. Zaznacza jednak, iż pojawiają się na scenie politycznej siły, które wskazują na konieczność przeprowadzenia reformy ustrojowej zrywającej z dziedzictwem okrągłego stołu oraz zastąpienia ułomnego państwa nową, Czwartą RP. Zob. R. Matyja, Zimna wojna domowa?, „Nowe Państwo" 1996, nr 1, s. 3.

Pismo wydawane było w latach 1997-2001. Łącznie ukazało się 8 numerów. Według Rafała Matyi powstanie „Kwartalnika Konserwatywnego” należałoby łączyć z poszukiwaniem wyrazistego programu przez Koalicję Konserwatywną. R. Matyja, Konserwatyzm po komunizmie, Warszawa 2009, s. 249. Wojciech Turek z kolei sugeruje, iż powiązanie redakcji pisma z Koalicją Konserwatywną miało charakter luźny i personalny, ale najbliżej było pismu właśnie do tej opcji politycznej. Rozmowa z Wojciechem Turkiem (wrzesień 2009, w zbiorach autora). O związku „Kwartalnika Konserwatywnego” z Koalicją Konserwatywną pisał również Włodzimierz Mich: W. Mich, Kwartalnik Konserwatywny, „Myśl Konserwatywna" 1998, nr 2/3.

4 B. Borowik, Ustrój państwa w polskiej publicystyce konserwatywnej lat dziewięćdziesiątych XX w., [w:] Między Europą naszych pragnień a Europą naszych możliwości, t II, red. J. Faryś, T. Sikorski, P. Słowiński, Gorzów Wielkopolski 2007.

S. Stępień, Ustrój polityczny III RP w koncepcjach programowych ruchu konserwatywnego, [w:] Konserwatyzm na Podlasiu, red. J. P. Gieorgica, Białystok 2005. 
Pismo to redagowane przez Rafała Matyję skupiało w swoich szeregach zarówno polityków (Robert Kostro, K. M. Ujazdowski), jak i publicystów (Dariusz Gawin, Marek Cichocki, Paweł Skibiński, Paweł Soloch, Artur Wołek). W redakcji zasiadali również ówczesni pracownicy administracji państwowej - Paweł Kowal czy też Tomasz Merta. Profil ideowy pisma pozwala nam umieścić je $w$ ramach polskiego neokonserwatyzmu ${ }^{6}$. $Z$ terminem tym związany jest jednak problem klasyfikacyjny, a mianowicie jednolite pojmowanie co najmniej dwóch środowisk politycznych, których partyjnymi emanacjami w latach 90. były: Partia Konserwatywna oraz Koalicja Konserwatywna. Problem ten ujawnia się nie tylko we wspomnianych wyżej pracach Stępnia oraz Borowika ${ }^{2}$. Można natomiast zaryzykować tezę, że oba ugrupowania nie były ideowo tożsame. Samo pismo z kolei, poprzez swoje powiązania chociażby personalne, znajdowało się $w$ orbicie Koalicji Konserwatywnej, nie zamykając przy tym swoich łam dla przedstawicieli innych ugrupowań.

W celu zrozumienia zawiłości związanych z podziałem w obrębie polskiego konserwatyzmu instytucjonalnego oraz osadzenia na politycznej mapie „Kwartalnika Konserwatywnego” przedstawić warto instytucjonalną historię środowisk politycznych interesującego nas nurtu. Wartość omawianego podziału jest uzasadniona szczególnie wobec idei IV RP. Jak opisuje Rafał Matyja, sprawa dogłębnej reformy państwa była niejako „rewizjonistyczna” w stosunku do SKL-u, a jej znaczenie doprowadziło nieistniejące już wówczas środowisko Koalicji do sojuszu z Prawem i Sprawiedliwością ${ }^{8}$. Pogląd o niechęci reszty neokonserwatystów do idei IV RP potwierdza opinia Lecha Mażewskiego na temat koncpecji Ujazdowskiego i Matyi, określająca ją jako „odkurzenie” głoszonej przez J. Kaczyńskiego idei „przyspieszenia” (poczynionej bez chłodnego, konserwatywnego namysłu):

Konrad Wandowicz neokonserwatystami określa zarówno środowisko polityczne Halla, jak i Ujazdowskiego. Wedle autora grupy te akceptują zasady suwerenności ludu, rozumianej jako rządy większości z poszanowaniem praw mniejszości. Neokonserwatyści, jak twierdzi, opowiadają się za uszlachetnieniem demokracji przez zaszczepienie jej chrześcijańskiego systemu wartości. Starają się połączyć gospodarczy liberalizm z ochroną tożsamości narodu. K. Wandowicz, Wspótczesny konserwatyzm polityczny w Polsce, Wrocław 2000, s. 212215; Substytucyjny podział na konserwatystów o orientacji zmodernizowanego tradycjonalizmu (SKL), konserwatystów liberalnych (UPR) oraz nurt konserwatywnonarodowy (ZChN) stosuje: Stefan Stępień, S. Stępień, Konserwatyści wobec zagadnień gospodarczych III RP, [w:] Konserwatyzm. Historia i wspótczesność, red. S. Stępień, Lublin 2003, s. 421. Odstępem od tendencji jednolitego traktowania omawianych tu grup jest praca R. Matyi, Konserwatyzm po....

Zob. K. Wandowicz, dz. cyt., A. Dudek, Konserwatyzm, [w:] Główne nurty wspótczesnej polskiej myśli politycznej, t. 1, red. B. Bankowicz, A. Dudek, J. Majchrowski, Kraków 1996.

Zob. R. Matyja, Konserwatyzm po..., s. 192. 
„[...] idea IV Rzeczypospolitej może być traktowana jedynie jako typowa utopia polityczna, niemająca nic wspólnego z ideą konserwatywną. Cały sens publicystyki tandemu Matyja-Ujazdowski sprowadza się do stwierdzenia, że ewolucyjne przejście PRL-u w niepodległe państwo zawiodło"

Jak zatem umiejscowić grupę polityczną „Kwartalnika Konserwatywnego" w nurcie neokonserwatywnym? Nie ulega wątpliwości, iż swoje źródła, tak jak i cały nurt, wywodzi ona z powstałego w 1979 roku Ruchu Młodej Polski. W listopadzie 1989 roku wywodzący się z Ruchu Młodej Polski: Tomasz Wołek, Aleksander Hall oraz Kazimierz M. Ujazdowski założyli Ruch Polityki Polskiej, który został przekształcony w czerwcu 1990 roku w Forum Prawicy Demokratycznej ${ }^{10}$. Zmiana ta była wynikiem połączenia się z utworzonym w 1984 roku Klubem Myśli Politycznej „Dziekania” oraz środowiskiem chrześcijańskich liberałów ${ }^{11}$. Nowo ukształtowana grupa polityczna w grudniu 1990 roku wraz z Ruchem Obywatelskim - Akcją Demokratyczną oraz komitetami wyborczymi Tadeusza Mazowieckiego utworzyła Unię Demokratyczną, tworząc w jej ramach wewnątrzpartyjną Frakcję Prawicy Demokratycznej ${ }^{12}$.

Neokonserwatyści w ramach UD nie funkcjonowali jednak długo. We wrześniu 1992 roku Forum Prawicy Demokratycznej, pod hasłem budowy własnego ugrupowania, opuściło szeregi unitów ${ }^{13}$, by w grudniu powołać do istnienia Partię Konserwatywną ${ }^{14}$. Startując w wyborach parlamentarnych 1993 roku w ramach Katolickiego Komitetu Wyborczego „Ojczyzna”, konserwatyści nie uzyskali żadnego mandatu (podobnie jak cały komitet). Porażka wyborcza oraz wynikająca z niej napięta sytuacja doprowadziły w roku 1994 do rozłamu i w konsekwencji utworzenia w kwietniu tego samego roku konkurencyjnego ugrupowania: Koalicji Konserwatywnej pod przewodnictwem K. M. Ujazdowskiego. Nowopowstała partia grupowała osoby, które kwestionowały kierunek polityki uprawianej przez Halla oraz

L. Mażewski, Konserwatyści wobec Polski pojaltańskiej, „Myśl Konserwatywna” 1998, nr 2/3, s. $117-118$.

A. Dudek, dz. cyt., s. 55.

Zob. tamże, s. 53-55.

K. A. Paszkiewicz, Unia Demokratyczna, [w:] Partie i koalicje polityczne III RP, red. K. A. Paszkiewicz, Wrocław 2004, s. 191-192.

Nowa partia miała być nowoczesną prawicą, dążącą do modernizacji kraju przy jednoczesnym zachowaniu szacunku do tradycyjnych wartości, w tym religijnych. K. SobolewskaMyślik, Partie i systemy partyjne Europy Środkowej po 1989 roku, Kraków 1999, s. 139-140. Koalicja Republikańska (grupa powstała w wyniku sprzeciwu części członków FPD wobec uczestnictwa w UD) oraz Górnośląski Okręg Kongresu Liberalno-Demokratycznego. B. Borowik, Działalność posłów Partii Konserwatywnej w Sejmie I kadencji (grudzień 92 - maj 93), [w:] Konserwatyzm. Historia i wspótczesność, red. S. Stępień, Lublin 2003, s. 399. 
zamierzały prezentować „wyrazistą tendencję prawicową" ${ }^{15}$. Jak sugeruje Bogdan Borowik, przyczyny konfliktu miały charakter zarówno personalny, jak i taktyczny ${ }^{16}$. Najostrzejszy spór dotyczył kierunku integracji prawicy. A. Hall dążył do dystansowania własnego ugrupowania wobec tradycjonalistycznych poglądów, dopuszczając możliwość współpracy z liberalnym centrum. K. M. Ujazdowski opowiadał się z kolei za współpracą z ugrupowaniami chrześcijańsko-narodowymi i niepodległościowymi, negując jednocześnie możliwość współpracy z takimi partiami jak Unia Demokratyczna czy Kongres Liberalno-Demokratyczny ${ }^{17}$. Dążył on do ukształtowania „obozu konserwatywnego o nieliberalnym obliczu, ale też wolnego od antyliberalnej fobii" ${ }^{, 18}$. Powyższe opinie potwierdza sam Ujazdowski, który powstanie KK łączy ze stosunkiem A. Halla do Przymierza dla Polski. Przewodniczący PK opowiadał się za koalicją konserwatywnoliberalną, tworzoną przy udziale UPR-u, Stronnictwa NarodowoDemokratycznego Jana Zamoyskiego oraz ugrupowań z byłej Konwencji Polskiej. Blok taki miał być uzupełniony, a w zasadzie oparty o siły powstałe z rozpadu UD. Wobec takiej koncpecji Kazimierz. M. Ujazdowski przeciwstawiał projekt budowy szerokiego bloku konserwatywnego opartego na PC oraz ZChN-ie ${ }^{19}$.

Dla swojego nowego ugrupowania Ujazdowski określił dwa główne zadania: bronić kultury przed „cywilizacją śmierci”, oraz walczyć o „odbudowę zdrowych instytucji politycznych i gospodarczych, o silne państwo, reformę administracji, upowszechnienie własności” ${ }^{20}$.

Drogi neokonserwatystów zeszły się jednak w drugiej połowie lat 90 . Hall mimo niepowodzenia PK nadal dążył do utworzenia znaczącego ugrupowania, czego przejawem było powstanie 12 stycznia 1997 roku Stronnictwa Konserwatywno-Ludowego ${ }^{21}$ mającego za zadanie zjednoczyć wokół siebie nurt konserwatywny obecny w nowo utworzonej wówczas Akcji Wyborczej „Solidarność”. W powstaniu SKL-u nie uczestniczyli politycy Koalicji Konserwatywnej, którzy w ramach jednoczącej się prawicy stawiali na samodzielną działalność, o czym świadczyć może próba (nieudana) zjed-

\footnotetext{
R. Matyja, Konserwatyzm po..., s. 136.

Zob. B. Borowik, Myśl konserwatywna..., s. 68.

Zob. K. A. Paszkiewicz, Koalicja Konserwatywna, [w:] Partie i koalicje..., s. 29.

R. Matyja, Konserwatyzm po..., s. 136.

Zob. K. M. Ujazdowski, Prawica dla wszystkich, Warszawa 1995, s. 42-43.

Cyt. za: R. Matyja, Konserwatyzm po..., s. 248.

W nowo utworzonym SKL-u znalazły się oprócz PK: Stronnictwo Ludowo-Chrześcijańskie oraz grupa chadecko-konserwatywnego skrzydła Unii Wolności (następczyni Unii Demokratycznej). K. A. Paszkiewicz, Stronnictwo Konserwatywno-Ludowe, [w:] Partie i koalicje..., s. 173 .
} 
noczenia neokonserwatystów w ramach Krajowego Komitetu Konserwatywnego ${ }^{22}$.

Wydarzenia polityczne z lat 1997-2001 przyniosły jednak szereg zmian $\mathrm{w}$ nurcie neokonserwatywnym. Stale rozszerzające się $\mathrm{SKL}^{23}$ i coraz silniejsza jego pozycja w strukturach AWS-u niejako wymusiły na Koalicji Konserwatywnej zgodę na zjednoczenie. Oficjalne przystąpienie KK do SKL-u nastąpiło podczas konwencji zjednoczeniowej w dniu 21 lutego $1999 \mathrm{roku}^{24}$.

Współdziałanie w jednym ugrupowaniu obu nurtów neokonserwatyzmu nie trwało długo. Podjęta na początku 2001 roku decyzja Rady Politycznej SKL o współpracy z PO odnowiła stare podziały i doprowadziła do kolejnego rozłamu ${ }^{25}$. Grupa niechętna współdziałaniu z PO podjęła współpracę z częścią członków ZChN-u oraz Ligą Republikańską ${ }^{26}$. Wynikiem wspólnego działania było utworzenie Przymierza Prawicy, które ostatecznie znalazło się w Prawie i Sprawiedliwości.

\section{Kryzys Państwa}

Kryzys Państwa dostrzegany przez środowisko „Kwartalnika Konserwatywnego" miał swój początek w braku reform ustrojowych mających dokonać zmian instytucjonalnych po 1989 roku. Szczególna krytyka zaniechania zmian dotyczyła okresu II kadencji parlamentu, kiedy to zaprzestano reform podjętych w początkowej fazie polskiej transformacji, jednocześnie powodując nawarstwianie się istniejących problemów. Objawem „kłopotów z państwem" według neokonserwatystów był bardzo niski stopień utożsamiania się z nim obywateli oraz brak myślenia w kategorii dobra wspólnego ${ }^{27}$.

22 Krajowy Komitet Konserwatywny miał przybrać formę „amerykańskich instytucji opiniotwórczych". Jednoczył w swoich szeregach nie tylko polityków, ale również i samorządowców, naukowców, dziennikarzy. Inicjatywa ta nie odniosła sukcesu. R. Matyja, Konserwatyzm po..., s. 249.

23 Kolejne rozszerzenie miało miejsce podczas kongresu SKL, na przełomie lutego i marca 1998 roku. Szeregi Stronnictwa zasilili wówczas politycy Partii Politycznej „Republikanie” oraz Porozumienia Centrum Inicjatywa Integracyjna, I. Zalewski, Konserwatywni sprinterzy i dhugodystansowcy, „Myśl Konserwatywna” 1998, nr 2/3, s. 213.

${ }^{24}$ M. D. Zdort, Spętane ręce i zasznurowane usta, „Rzeczpospolita” 1999, nr 44, s. 2. Ponadto SKL uległo jeszcze jednemu rozszerzeniu. W marcu 2000 roku, przyłączyło się do niego ugrupowanie: Chrześcijańska Demokracja - Stronnictwo Pracy. K. A. Paszkiewicz, Stronnictwo Konserwatywno..., s. 173.

Podobne pęknięcia miały miejsce zarówno podczas wstępowania Forum Prawicy Demokratycznej w szeregi Unii Demokratycznej, jak i wówczas, gdy powstawała KK będąca wynikiem opozycji do dominującej w PK koncepcji współpracy z politycznym liberalnym centrum.

${ }^{26}$ F. Gawryś, B. Waszkiewicz, Z Akcji do nowej prawicy, „Rzeczpospolita” 2001, nr 73, s. 4.

27 Zob. F. Morski, Decentralizacja jako naprawa państwa, „Kwartalnik Konserwatywny” 1998, nr 3, s. 41-42. 
Negatywne oceny rządów koalicji SLD-PSL potęgowały i tak dekadencki już opis sytuacji w kraju. Jak sugerował pomysłodawca przemian ustrojowych R. Matyja, „Celem komunistów nie jest odrodzenie PRL, lecz budowa takiego kształtu Trzeciej Rzeczypospolitej, w którym nie zaistnieje realne zagrożenie dla ich pozycji i stanu posiadania" ${ }^{28}$. Ta konkluzja, opócz krytyki postkomunistycznych rządów z lat 1993-1997, prezentuje również kierunek w jakim iść miałaby ewentualna zmiana systemu politycznego. Nie byłaby ona ufundowana na antypeerelowskiej płaszczyźnie ale raczej ukierunkowana na tworzenie nowego państwa przeciwstawnego wobec zaistniałego po 1989 roku ładu. „Nowy projekt [IV RP - przyp. A. L.] to odpowiedź na zatrzymanie w $1993 \mathrm{r}$. reform. Trzecia RP to państwo prywatnych i partyjnych interesów. [...] Czwarta RP to nie rebelia przeciwko Trzeciej, lecz konieczność budowy nowego państwa, [...] nadanie mu nowego ustroju, nowych praw i instytucji" ${ }^{29}$. Wartym podkreślenia faktem jest, iż retoryka antypeerelowska nie pojawiała się również w okresie przed powstaniem idei IV RP. Pisząc jeszcze w 1994 roku o potrzebie reform, Matyja sugerował, iż III RP to nie proste odrzucenie PRL-u, ale swego rodzaju spór z jego dziedzictwem $^{30}$. Nie było jednak zgody na zachowanie ciągłości historycznej systemu sprzed i po 1989. Taki zarzut stawiano natomiast konstytucji z 1997 roku. Jak twierdzono, zapisy ustawy zasadniczej były zgodą na próbę legitymizowania Polski Ludowej, a tym samym osób wywodzących się z aparatu komunistycznego państwa. „Dziedzicom PZPR zależy - i po części w świadomości społecznej udaje im się to osiągnąć - na wykazaniu ciągłości prawnej i politycznej Polski Ludowej z Trzecią Rzeczpospolitą" ${ }^{31}$.

Zmiany systemowe realizowane po 1989 roku okazały się według Matyi niedostateczne. W nowej rzeczywistości elity polityczne nie chciały podjąć trudu pracy nad „doktryną legitymizacyjną tego państwa”. Nie podjęto się zadania odbudowy „normalnego” państwa, którego podstawowe funkcje to: ochrona bezpieczeństwa, sprawny wymiar sprawiedliwości, egzekucja podatków i długów, sprawne funkcjonowanie infrastruktury ${ }^{32}$. Jak

\footnotetext{
R. Matyja, Rachunek z datą 1996!, „Nowe Państwo” 1996, nr 22, s. 7.

Tenże, Między trzecią a czwartą Rzeczypospolita, , „Nowe Państwo” 1997, nr 15, s. 4-5.

Zob. Tenże, Państwo czyli kłopot, „Debata” 1994, nr 2, s. 18.

Z. Wawak, Sądowe bezprawie, „Kwartalnik Konserwatywny” 1998, nr 3, s. 34. Środowisko Kwartalnika Konserwatywnego było negatywnie ustosunkowane wobec Konstytucji z 1997 roku. Główne argumenty przeciwko Ustawie Zasadniczej koncentrowały się na rozproszeniu władzy wykonawczej, braku konstytucyjnej ochrony tak rodziny, jak i własności prywatnej, nie wyznaczeniu cezury między PRL a III RP czy też poszerzaniu praw zatrzymanego. K. M. Ujazdowski, Konserwatyści wobec konstytucji, „Kwartalnik Konserwatywny” 1999, nr 5, s. $9-10$.

Zob. R. Matyja, Kryzys myśli politycznej, „Nowe Państwo” 1996, nr 6, s. 7.
} 
konstatował redaktor naczelny „Kwartalnika”, zmiany zostały zatrzymane, a rozpoczął się czas stabilizacji, szczególnie widoczny w okresie rządów SLDPSL. Brak ustanowienia powiatu samorządowego i uregulowania kwestii samorządu gospodarczego, brak reformy systemu ubezpieczeń społecznych i zdrowotnych, pozostawienie bez zmian służb specjalnych, wojska oraz policji czy też skonsolidowanej administracji rządowej tylko potwierdzały to przypuszczenie $^{33}$. Koalicja SLD-UP, zdaniem Matyi, kierowała reformami tak, aby zmierzały one ku stworzeniu gwarancji powstrzymywania reformy państwa oraz ku tworzeniu nowych powiązań między władzą nad instytucjami gospodarczymi a panowaniem nad administracją ${ }^{34}$. Podstawowym skutkiem takiego procesu było osłabienie instytucji państwa, które albo źle realizowało swoje funkcje, albo uchylało się od pełnienia swoich podstawowych obowiązków ${ }^{35}$.

W takich też okolicznościach pojawiła się krytyka III RP wynikająca nie z potrzeby radykalnych przemian, ale będąca raczej odpowiedzią na stagnację reform kształtującego się po 1989 roku systemu. Według Manifestu Konserwatystów ogłoszonego przez Krajowy Komitet Konserwatywny, Trzecia Rzeczpospolita nie była nowym państwem, „o które upomniała się polska prawica lat osiemdziesiątych. Nie zostały zbudowane instytucje chroniące bezpieczeństwo Rzeczpospolitej, jej politycznych i gospodarczych interesów na arenie miedzynarodowej czy też gwarantujące skuteczny wymiar sprawiedliwości. Rząd nadal ingerował w sprawy lokalne, wspierał jedne przedsiębiorstwa przeciw innym. Nadal utrzymywał na koszt podatników szereg rozbudowanych i nieefektywnych struktur administracyjnych i monopoli gospodarczych" ${ }^{36}$. Potrzebna jest zatem, budowa nowego państwa, gdyż dotychczas reformy powstrzymane zostały przez siły postkomunistyczne, z kolei uchwalenie konstytucji w 1997 roku zamknęło szanse na ewolucyjne zmiany ustrojowe. Budowa nowych struktur wymaga zatem silnego impulsu politycznego ${ }^{37}$.

Prezentując poszczególne problemy ustrojowe redaktorzy „Kwartalnika Konserwatywnego” zwracali szczególną uwagę na takie kwestie, jak funkcjonowanie sądownictwa, sprawność władzy wykonawczej oraz potrzeba decentralizacji i dekoncentracji. W obrębie zainteresowań autorów znajdowały

Zob. tenże, Między Trzecią a..., s. 4-5. Tenże, Fikcyjny obóz reform, „Nowe Państwo” 1997, nr $39, \mathrm{~s} 4$.

Zob. tenże, Obóz Czwartej Rzeczypospolitej, „Debata” 1998, nr 3, s. 9.

Tamże.

Krajowy Komitet Konserwatywny. Manifest Konserwatystów, „Kwartalnik Konserwatywny” 1998 , nr 3, s. 172.

Zob. Apel Konserwatywny - III Zjazd Koalicji Konserwatywnej, Katowice 20 IV 1997, „Kwartalnik Konserwatywny" 1997, nr 2, s. 78. 
się również zagadnienia związane z szeroko rozumianym państwowym systemem finansowym.

Będąc zwolennikami silnej władzy wykonawczej konserwatyści sugerowali, iż brak dobrze zorganizowanej egzekutywy obniża możliwości polityki polskiej. Zauważali oni, iż po 1989 roku odziedziczony został rząd zgodny z modelem radzieckim, będący federacją resortów. System ten silnie związany z formułą „partia kieruje, a rząd rządzi”, w warunkach systemu demokratycznego kształtującego się w Polsce po 1989 roku prowadził do ograniczenia się tylko i wyłącznie do administrowania ${ }^{38}$. Problem ten uwidaczniał się szczególnie, gdyż po 1989 roku w ciągu pierwszych kilku lat nie dokonano zmian ustrojowych, które dałyby stabilną i skuteczną władzę wykonawczą. Brak reform przyniósł zatem naturalne problemy $\mathrm{z}$ funkcjonowaniem egzekutywy ${ }^{39}$.

Kazimierz M. Ujazdowski krytykował zmiany, jakie rzekomo miała przynieść reforma centrum rządu dokonana przez koalicję SLD-PSL. Zdaniem lidera Koalicji Konserwatywnej premier nie uzyskał w jej wyniku prawnych i organizacyjnych możliwości narzucenia spójnej polityki całej Radzie Ministrów ${ }^{40}$, nie nabył on również możliwości wpływania na proces kreowania budżetu. Główną funkcję w tym wymiarze zachował minister finansów, a właściwie biurokracja tego ministerstwa ${ }^{41}$.

Uwagi o kryzysie państwa ukierunkowane były również na stan sądownictwa w Polsce. Słabość, jaką dostrzegali publicyści związani z „Kwartalnikiem Konserwatywnym”, była pochodną sytuacji sądownictwa z czasów państwa komunistycznego. Jak opisywał przywoływany już Ujazdowski, w sądownictwie III RP uwidaczniały się: wymagająca zmiany słabość instytucji, niski poziom merytoryczny kadry sędziowskiej oraz anachroniczna infrastruktura sądowa. W opinii Ujazdowskiego po 1989 roku niesłusznie zrezygnowano z reform, które usunęłyby wyżej wymienione wady. Zamiast podjęcia się trudu naprawy, wprowadzono szerokie uprawnienia dla samorządu sędziowskiego, co automatycznie ograniczyło wpływ rządu na jakość pracy sądów. Głównym zatem zadaniem powinno być przywrócenie sądom wysokiego poziomu moralnego oraz merytorycznego ${ }^{42}$. Problem moralności sędziów wiązał się jednak ściśle z biografiami pracowników sądów. Zdaniem Ujazdowskiego, wielu sędziów czynnych zawodowo po 1989 roku, w okresie

\footnotetext{
38 Zob. K. M. Ujazdowski, Dobry i sprawny rząd, [w:] Dobry i sprawny rząd, red. K. M. Ujazdowski, Warszawa 1997, s. 5.

Zob. tamże, s. 7.

Tamże, s. 11-12.

Tamże, s. 10.

Tenże, Naprawa sądownictwa, „Kwartalnik Konserwatywny” 1998, nr 3, s. 26.
} 
państwa komunistycznego sprzeniewierzyła się zasadzie niezawisłości sędziowskiej. Receptą na ten stan rzeczy miało być samooczyszczenie się środowiska sędziowskiego, które jednak okazało się „myśleniem życzeniowym" $^{\text {"43 }}$. Ostatecznie poziom kwalifikacji kadr sędziowskich, jak również długość rozpatrywania spraw sprawił, iż w III RP sądownictwo straciło swoją wiarygodność, co miało niewątpliwy wpływ na postrzeganie całego państwa .

$\mathrm{Na}$ kryzys państwa składać się miała również scentralizowana i zbiurokratyzowana struktura przejęta po państwie PRL. Za dominujące w niej uznano silne, pionowe struktury branżowe. Państwo tak skonstruowane charakteryzowało się bardzo szerokim zasięgiem działania i aż nadto zaangażowaniem w sprawy społeczne ${ }^{45}$. Aparat państwowy ingerujący niejako w życie obywateli nie mógł być jednak adekwatny do zadań nowoczesnego państwa. Państwa, które angażując się w sprawy jednostek stawało się tym mniej sprawne $\mathrm{w}$ realizowaniu przysługujących mu podstawowych zadan ${ }^{46}$.

\section{RP - Nowe państwo}

Rozważania na temat kryzysu państwa w środowisku „Kwartalnika Konserwatywnego" w latach 1997-2001 były niejako rozwinięciem i dostosowaniem do ówczesnych warunków politycznych koncepcji pojawiających się w tym obozie politycznym co najmniej od 1993 roku. Trzeba jednak zaznaczyć, iż w pierwszej fazie zgromadzeni wokół Matyi politycy oraz publicyści nie występowali z projektem IV RP, a sugerowali raczej, iż nowym państwem może zostać III RP, poddana szeregowi reform ${ }^{47}$. Nowe państwo byłoby zatem skutkiem ewolucyjnych przemian struktur wywodzących się z czasów PRL-u ${ }^{48}$. Zaniechania popełnione przez kolejne rządy a w szczególności przez koalicję SLD-PSL i ciągle pogłębiające się problemy doprowadziły jednak do wykreowania idei niejako radykalnego wstrząsu, który dzięki swojemu nowatorstwu i dogłębnej zmianie doprowadziłby do wytworzenia „zdrowych" instytucji państwa. Niezrealizowane reformy, według „Kwartalnika Konserwatywnego”, mogły zostać zastąpione tylko przez „wstrząs”, jakim był projekt IV RP.

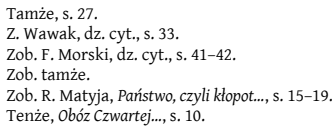


Jak zapowiedział Rafał Matyja: „Prawica konserwatywna nie ma innego wyboru jak wystąpić z hasłem budowy Czwartej Rzeczypospolitej" ${ }^{49}$. Jak zatem powinna wyglądać „nowa” Rzeczpospolita i w jaki sposób miałaby być stworzona? Zdaniem jednego z redaktorów „Kwartalnika” przebudowa państwa zmierzać powinna ku przywróceniu systemowi politycznemu zgodności z naturalnymi zadaniami państwa. Przemiany miałyby uwidaczniać się w przebudowie instytucji politycznych i gospodarczych, odbudowie własności prywatnej, instytucji państwa prawa i samorządności lokalnej. W taki sposób określono warunki przygotowania państwa do wypełniania przez niego podstawowych zadan ${ }^{50}$. W budowie nowego państwa konieczne powinno być jednak zwracanie uwagi, jak sugeruje Waldemar Rataj, na odczytanie polskiej doktryny ustrojowej, której istotnym elementem jest „specyficzne polskie doświadczenie" ${ }^{51}$. Nie uczyniono tego na początku transformacji, z tego też powodu III Rzeczpospolita skonstruowana została na podstawie kontraktu elit. Zamiast odczytywać do czego państwo ma służyć, skupiono się na zachowaniu procedur demokratycznych oraz uzgodnieniowych ${ }^{52}$.

Takie dokumenty, jak Apel Konserwatywny czy Manifest Konserwatystów, wsparte publicystyką środowiska rysują obraz „państwa silnego i zdecentralizowanego z nowoczesną gospodarką i poddanymi kontroli służbami chroniącymi jego bezpieczeństwa" ${ }^{53}$. Jak powiedzą konserwatyści, „Polska potrzebuje zmian ustrojowych usuwających patologię instytucji PRL$\mathrm{u}$ - dawnych służb specjalnych, dominacji układów branżowo - resortowych, marnotrawionych funduszy państwowych oraz korupcyjnych powiązań gospodarczo-politycznych ${ }^{54}$.

Występują zatem konserwatywni instytucjonaliści z propozycją państwa, którego władze będą rzeczywistym suwerenem zarówno wobec podmiotów zewnętrznych, jak i struktur wewnętrznych. Państwa, które w praktyce będzie stosować zasadę pomocniczości, a zatem zdecentralizowanego, odchudzonego, pozostawiającego szeroki zakres spraw instytucjom

Tenże, R. Matyja, Fikcyjny obóz..., s. 4.

Zob. R. Kostro, Kim są konserwatyści, „Kwartalnik Konserwatywny” 1997, nr 1, s. 108.

$\mathrm{Na}$ podstawie doświadczenia powinno się budować ustrój, który strzegłby wolności i godności osób oraz gwarantowałby ramy społecznej solidarności. Polska doktryna ustrojowa powinna zwracać uwagę na negatywne doświadczenia III RP (patologie wynikające ze styku polityki i biznesu), ale również doszukiwać się pozytywnych elementów, takich jak np. funkcjonowanie samorządu terytorialnego. Zob. W. Rataj, Doktryna państwowa Trzeciej Rzeczypospolitej, „Kwartalnik Konserwatywny” 1997, nr 1, s. 23-25.

Zob. tamże, s. 25

Apel Konserwatywny..., s. 79.

Zob. Krajowy Komitet Konserwatywny..., s. 173. 
pozarządowym. Państwa, w którym zasada własności prywatnej będzie miała charakter zasady konstytucyjnej, a nie jednej z cech porządku gospodarczego ${ }^{55}$.

Zmiany w państwowej konstrukcji powinny rozpocząć się od wymiany „elementów nośnych”, czyli służb specjalnych, aparatu skarbowego i finansowego oraz układu kapitalizmu oligarchicznego. Nowe państwo miałoby opierać się na nowych filarach, takich jak: samorząd terytorialny, nowy korpus urzędniczy oraz ekspercki, zbudowane na nowo ośrodki informacji i wiedzy oraz odbudowany wymiar sprawiedliwości ${ }^{56}$. W sformułowanych na łamach „Kwartalnika” Dziewięciu tezach w sprawie polityki rządu zawarto propozycje działań mających przyczynić się do budowy dobrego państwa: reforma administracji publicznej (decentralizacji państwa), uzdrowienie finansów publicznych, przywrócenie bezpieczeństwa i sprawiedliwości, stworzenie warunków dla konkurencyjnej gospodarki. Proponowane zmiany miałyby stać się ustrojowymi podstawami Czwartej Rzeczypospolitej, czyli państwa „sprawiedliwego, o silnym ale ograniczonym do minimum rządzie, szanującego prawa wspólnot lokalnych, uznającego własność prywatną za naczelną zasadę ustrojową"

Koncepcja omawianej reformy ustrojowej ukierunkowana była na przezwyciężenie głębokiej słabości państwa, będącej instytucjonalnym spadkiem po okresie PRL-u. W tym kontekście koniecznym stawało się „odtworzenie narzędzi sprawnego działania". W innym przypadku skrępowany rząd nie miałby zdolności reformowania państwa ${ }^{58}$. Odnośnie III RP za główną przyczynę kryzysu uznano: autonomizację policji, wojska isłużb specjalnych, jak również suwerenną politykę prowadzoną przez ministerstwo finansów oraz resort spraw zagranicznych. Przyczyną była również instytucjonalna słabość zaplecza centrum rządu oraz wyprowadzenie poza sferę władzy publicznej instytucji dysponujących sporymi sumami środków publicznych $^{59}$.

Kluczowym dla projektu IV RP wnioskiem była zatem kwestia wzmocnienia władzy wykonawczej. Reforma zmierzać powinna ku uczynieniu z premiera rzeczywistego szefa egzekutywy oraz odbudowaniu centrum rzą-

\footnotetext{
Zob. R. Matyja, Fikcyjny obóz..., s. 4.

Zob. tenże, Obóz Czwartej.., s. 12.

M. Biernacki, M. Kamiński, J. Polaczek, K. Śmieja, K. M. Ujazdowski, Dziewięć tez w sprawie polityki rządu, „Kwartalnik Konserwatywny” 1997, nr 2, s. 6-9.

R. Matyja, Przywództwo państwowe czy administrowanie, [w:] Dobry i sprawny rząd, red. K. M. Ujazdowski, Warszawa 1997, s. 15-16.

Zob. tamże.
} 
$\mathrm{du}^{60}$. W wypadku powodzenia tegoż planu premier mógłby wyznaczać i egzekwować jednolitą linię działania całego gabinetu, mógłby również odpowiadać za pracę nad budżetem ${ }^{61}$. Pozycja prezesa Rady Ministrów powinna być zatem wzmocniona szczególnie w stosunku do podległych mu instytucji władzy wykonawczej ${ }^{62}$. Ponadto mogłoby nastąpić wzmocnienie skuteczności i spoistości działania Rady Ministrów. Ministrowie powinni wówczas stać się reprezentantami woli politycznej rządu nie zaś reprezentantami resortów i związanych z nimi grup interesów ${ }^{63^{\circ}}$.

Z reformą władzy wykonawczej związane było jeszcze jedno pojęcie, a mianowicie przywództwo państwowe. Zostało ono zdefiniowane w licznych artykułach Matyi. Oznaczało osobę lub grupę osób, które piastowanie wysokich stanowisk państwowych wykorzystywałyby nie do celów prywatnych, lecz do wypełniania zadań państwowych, do których władza rzeczywiście jest powołana. Posiadanie przywództwa na odpowiednim poziomie umożliwiłoby nie tylko formułowanie celów polityki państwa ale i zdolność ich osiągania ${ }^{64}$. W polskich warunkach zrealizowanie tego postulatu wiązało się z koniecznością wzmocnienia władzy wykonawczej rozmytej pomiędzy urzędami prezydenta oraz premiera. Według redaktorów „Kwartalnika" ani zaplecze prezydenckie ani umiejscowione w kancelarii Premiera nie były w stanie formułować strategii państwowej tak potrzebnej do skutecznego „konkurowania z innymi narodami Europy” ${ }^{\text {"65 }}$.

Władza wykonawcza to również konieczność reformy administracji państwowej. Tylko bowiem zdecentralizowane państwo z ograniczoną administracją specjalną w terenie będącą poza kontrolą wojewody (reprezentanta rządu), sprawiłoby według redaktorów „Kwartalnika”, że rząd będzie mógł

W0 W ramach reformy centrum redaktorzy „Kwartalnika” proponowali ograniczyć do minimum istnienie ciał konsultacyjnych podejmujących wstępne decyzje. Zwracali też uwagę na kwestie obecnych w administracji rządowej reprezentantów partykularnych interesów podmiotów zewnętrznych do rządu (nieformalne grupy administracyjno-gospodarcze) R. Matyja, Naprawa rządu - warunek naprawy państwa, „Kwartalnik Konserwatywny” 1999, nr 5, s. 41-42.

${ }^{61}$ Zob. K. M. Ujazdowski, Dobry i sprawny..., s. 11-13. W kontekście konstruowania budżetu, na łamach „Kwartalnika” zwracano również uwagę na przestarzałe metody jego tworzenia. Reforma państwa miałaby zatem dotyczyć kwestii działalności ministerstwa finansów w pracach nad budżetem. Dotychczasowy system koncentrował planowanie budżetu w jednym ośrodku (Ministerstwie Finansów), nie konsolidował budżetu funduszy celowych z budżetem państwa, nie posiadał instytucjonalnego rozwiązania kwestii zarządzania długiem publicznym, zbyt słabo monitorował realizację budżetu. M. Budzisz, Budżet: reforma o której zapomniano, „Kwartalnik Konserwatywny” 1999, nr 5, s. 49-51.

Zob. R. Matyja, Naprawa rzadu..., s. 34-35.

Zob. tamże.

Zob. tenże, Przywództwo państwowe, „Kwartalnik Konserwatywny” 1998, nr 3, s. 17.

Tamże, s.10-12. Zob. tenże, Prezydentura dla Polski?, „Nowe Państwo” 1996, nr 5, s. 10. 
w pełni realizować swoje podstawowe funkcje ${ }^{66}$. Reforma państwa oznaczałaby ponadto deregulację (zniesienie rozbudowanego systemu koncesji i innych środków administracyjnych) oraz dekoncentrację oznaczającą budowę szczebla administracji centralnej, niebędącej rządem, natomiast wykonującej ustawy $^{67}$.

Jak sugeruje Marek Budzisz nie należało jednak fetyszyzować przekształceń administracyjnych o charakterze strukturalnym. Uznano je co prawda za bardzo ważne, aczkolwiek „prawdziwy skok jakościowy” można by uzyskać, gdyby nacisk położony został na „trudny do zdefiniowania acz zauważalny etos funkcjonowania administracji”. Konieczne są bowiem „niewielkie, elastyczne, przesiąknięte duchem przedsiębiorczości i nastawione na zaspokojenie oczekiwań klientów nowe jednostki administracji publicznej" ". Niestety, jak konstatowali redaktorzy „Kwartalnika”, polska administracja cechowała się nieudolnością w przygotowywaniu aktów prawnych oraz niskim poziomem etyki zawodowej pracowników, co przekładać się miało na niski stopień zaufania społecznego do aparatu publicznego ${ }^{69}$. Receptę na taki stan rzeczy widziano w profesjonalnym i apolitycznym funkcjonowaniu służby cywilnej, permanentnym rozwoju jej członków, a także dbaniu o kodeks etyki pracowniczej ${ }^{70}$. Swoje znaczenie dla funkcjonowania administracji miało, według Michała Kuleszy, także niedokonanie po 1989 roku bardzo ważnej zmiany w administracji. W ramach władzy publicznej nie dokonano bowiem podziału na władzę administracyjną oraz władzę polityczną. Z tego też powodu nie zaistniała odpowiedzialność polityczna ani też odpowiedzialność administracyjna ciążąca na urzędnikach ${ }^{71}$.

Podobnie jak wzmocnienie władzy wykonawczej, tak i idea samorządu terytorialnego w koncepcjach „Kwartalnika Konserwatywnego” znajdowała się na czołowym miejscu. Dla konserwatystów państwo w praktyce powinno kierować się zasadą pomocniczości i rezygnować z działania w sprawach, które mogłyby być realizowane przez władze lokalne, samorządy zawodowe lub obywateli.

\footnotetext{
Zob. K. M. Ujazdowski, Dobry i sprawny..., s. 11-13.

W nowym systemie administracji ministerstwa powinny ograniczyć zatrudnienie oraz przekształcić się w zaplecze informacyjne i merytoryczne dla działań rządu. Wówczas w jego (ministerstwa) skład wchodziłaby służba cywilna oraz gabinet polityczny. Służba Cywilna pełniłaby funkcję pamięci instytucjonalnej, zaś Gabinet Polityczny gromadziłby osoby politycznie związane w ministrem. M. Kulesza, Jaka administracja potrzebna jest Polsce, [w:] Dobry i sprawny rząd, red. K. M. Ujazdowski, Warszawa 1997, s. 39-41.

M. Budzisz, dz. cyt., s. 55.

69 Zob. T. G. Grosse, Polska administracja - potrzeba następnego kroku, „Kwartalnik Konserwatywny" 2000, nr 6, s. 93-95.

Zob. tamże.

Zob. M. Kulesza, dz. cyt., s. 43.
} 
Sprawę decentralizacji oraz dekoncentracji odnoszono do unitarności państwa. Wnoszono sprzeciw wobec jakiejkolwiek idei regionalizacji kwestionującej unitarny charakter Rzeczypospolitej ${ }^{72}$. Jak stanowił Apel Konserwatywny: „Przeciwstawienie wspólnot lokalnych i regionalnych interesowi państwa jako całości uważamy za sprzeczne z Polską tradycją narodową i współczesnymi potrzebami Polaków" ${ }^{\text {"73 }}$. Konstatowano jednak, iż decentralizacja poprzez nadzór sprawowany przez wojewodę oraz dekoncentracja przy zachowaniu nadzoru oraz podporządkowania hierarchicznego wobec szczebla centralnego nie stanowią zagrożenia dla unitarnej formy państwa. W oczach Pawła Skibińskiego samorząd nie otrzymywał bowiem ani uprawnień prawodawczych, ani też nie zyskiwał możliwości kreacji własnego systemu finansów publicznych ${ }^{74}$.

Odnosząc się do kryzysu systemu sądownictwa, neokonserwatyści nie proponowali radykalnych rozwiązań. Sugerowali, iż niezawisłość sędziów, jak i niezależność sądów powinny pozostać trwałymi elementami nowego państwa. Reformą usprawniającą sądownictwo powinno być natomiast przywrócenie równowagi między uprawnieniami samorządu sędziowskiego a kompetencjami ministra sprawiedliwości w zakresie nadzoru administracyjnego, a w szczególności zwiększenie możliwości oddziaływania władzy na pozajudykatywną stronę pracy sądów ${ }^{75}$.

Czwarta Rzeczypospolita to również zmiany w społeczeństwie. Bez obudzenia w społeczeństwie poczucia odpowiedzialności za sprawy publiczne nie zostałby odniesiony sukces zmian instytucjonalnych, które ugrzęzłyby w „morzu sporów”. W opinii środowiska „Kwartalnika” najważniejsze źródła siły społeczeństwa to: własność prywatna zapewniająca podstawy egzystencji rodzin, społeczności lokalne stanowiące o fundamencie trwałości państwa oraz system wychowawczo oświatowy dbający o wysoki poziom kultury społeczeństwa ${ }^{76}$. Pielęgnowanie tych wartości stawało się niezbędnym elementem dla powodzenia zmian.

\footnotetext{
Zob. Apel Konserwatywny..., s. 80.

Tamże, s. 80. Środowisko „Kwartalnika” wyrażało sprzeciw wobec jakiejkolwiek formie autonomii, której konsekwencją byłoby utracenie przez państwo polskie zwierzchności na całości swojego terytorium. P. Skibiński, Polska państwem unitarnym, „Kwartalnik Konserwatywny" 1998, nr 3, s. 38-39.

Zob. P. Skibiński, dz. cyt., s. 38-39.

Zob. K. M. Ujazdowski, Naprawa sądownictwa..., s. 28.

Zob. B. Borowik. Myśl konserwatywna..., s. 69.
} 


\section{Podsumowanie}

Obserwacje polskiej transformacji oraz jej błędów wzmocnione przez poczucie niechęci do dalszego naprawiania państwa doprowadziły opisywane środowiska konserwatywne do stworzenia zalążka projektu „naprawczego”. „Formułujemy hasło Czwartej Rzeczpospolitej aby wskazać pożądany horyzont zmian ustrojowych dla cełej prawicy" ${ }^{77}$. W taki oto sposób K. M. Ujazdowski określił projekt intelektualny obecny na łamach „Kwartalnika Konserwatywnego". Projekt IV RP nie był bowiem propozycją nowej konstytucji. Nie był też całościową propozycją nowego konkretnego ustroju państwa. Proponowana idea nowego państwa była raczej ofertą zalążka zmian systemu politycznego, który zastygł $\mathrm{w}$ toku swojej transformacji. Okrzepł on jednak w postaci niezdolnej do prawidłowego funkcjonowania. Środowisko „Kwartalnika” zwracało zatem uwagę na fakt potrzeby dokończenia, a w zasadzie rozpoczęcia na nowo procesu reform systemowych. Reform nie rewolucyjnych, niszczących wszystko, co było przedtem, ale zmian ewolucyjnych. Czwarta Rzeczpospolita nie miała być bowiem zaprzeczeniem Trzeciej, ale powinna czerpać z niej nie tylko doświadczenie funkcjonowania, ale również i te z instytucji, które posiadały charakter „nowości”,

Wzmocnienie państwa, w szczególności jego egzekutywy połączone z wzmocnieniem samorządu oraz usprawnieniem sądownictwa, to najważniejsze, ale nie jedyne propozycje prezentujące kierunek zmian. Silne, ale i ograniczone w swojej władzy państwo to cel, jaki przyświecał konserwatystom w tworzeniu idei IV RP. Ostatecznie jednak zamiar ten nigdy nie został spełniony. Nawet w okresie rządów Prawa i Sprawiedliwości, kiedy mogłoby się wydawać, iż przynajmniej część z postulatów zostanie spełniona, nie udało się dokonać kluczowych dla neokonserwatystów zmian.

A R K A D I S Z L E W A N D O W S K I

K. M. Ujazdowski, Konserwatyzm na prawicy, „Kwartalnik Konserwatywny” 1997, nr 2, s. 19.

Zob. R. Matyja, Obóz czwartej..., s. 12. 


\section{Abstract}

The main goal of the article is to present an issue of crisis and reforms held in Poland. The author emphasises the idea of the Fourth Republic of Poland (IV RP), which was created by the editorial staff of 'Kwartalnik Konserwatywny' in the second part of 1990s. This political magazine was strictly connected with Conservative Coalition (Koalicja Konserwatywna) and its prominent members such as Kazimierz M. Ujazdowski, Rafał Matyja, Paweł Soloch, Pawel Kowal and Tomasz Merta.

The crisis of Polish state was the visible outcome of the lack of reforms at the beginning of 1990s. In such conditions, the members of Conservative Coalition suggested modification of Polish political system. Proposed changes concerned executive power, an intelligence agency, public finance system and local government. Nevertheless, the idea of Fourth Republic of Poland was not a draft bill of constitution, but only the suggestion for altering current political system. 